\title{
Squandering the territorial capital in the Balkans? Urban megaprojects between global trends and local incentives
}

\author{
Ana Peric ${ }^{1,2} \cdot$ Frank D'hondt ${ }^{3}$ \\ Accepted: 9 November 2020 / Published online: 3 December 2020 \\ (c) The Author(s) 2020
}

\begin{abstract}
Throughout its history, but also squeezed between the current challenges of globalisation and sovereignty, the Balkans has been confronted with a number of different political, economic, environmental, and cultural problems. Such a complex social framework inevitably implies spatial degradation, not only in terms of the urban forms as the final planning product, but also in terms of the nature of the planning process and urban governance. Notably, we assume that territorial capital in the Balkans is under serious threat due to the abuse of legal procedures, the neglect of the public interest and the politicisation of planning. To elucidate this, we focus on the megaprojects Belgrade Waterfront (Belgrade) and Hellinikon (Athens) as examples of urban development that require exceptional conditions such as special regulations, additional funding, long-term timeframes, and ad hoc actor networks. Against the conceptual background of multi-level governance and based on in-depth case studies, we examine the nature of vertical cooperation between authorities at different levels (from supranational to local), horizontal cooperation amongst different stakeholders, and the role of planning professionals who are seen as facilitators in this process. Finally, we point out to the most important conditions that enable a democratic social, political and professional framework for urban megaprojects.
\end{abstract}

Keywords Urban development $\cdot$ Megaprojects $\cdot$ Multi-level governance $\cdot$ Belgrade Waterfront $\cdot$ Hellinikon

\section{Introduction: the Balkans' position against global trends in spatial and territorial development}

The Balkans is one of the largest regions in Europe. In geographical terms, it covers an area of the Balkan Peninsula bounded by the Adriatic Sea to the west, the Mediterranean Sea (including both the Ionian and Aegean Seas) and the Marmara Sea to the south, and the Black Sea to the east, and the Kupa-Sava-Danube river line to the north (Fig. 1). However, as there is no consensus on the northern border of

Ana Peric

aperic@ethz.ch

Frank D'hondt

frank@territorialcapital.institute

1 Institute for Spatial and Landscape Development, ETH Zurich (Swiss Federal Institute of Technology), Stefano-Franscini-Platz 5, 8093 Zurich, Switzerland

2 Faculty of Architecture, University of Belgrade, Belgrade, Serbia

3 Territorial Capital Institute, Athens, Greece the peninsula itself, geography is only one aspect that brings to the complexity of the region. Namely, the Balkans, as a term extending beyond the physical borders of the peninsula, is synonymous with a diversity of cultures, religions, languages, ideologies, and ethnographies (Fig. 2).

The Balkans had a highly turbulent past (Faludi 2018; Hajdu and Racz 2011; Diklic 2014; Aleksic 2020; Zizek 1999; D'hondt 2017; Nedovic-Budic and Cavric 2006). Ancient Greece, i.e. the city-state of Athens, is considered a cradle of western civilization, whilst Byzantium later became the economic, cultural, and political centre of all of Europe. However, the legacies of the Western Roman Empire, together with those of the mediaeval states of Serbia and Bulgaria, were highly contested by the Ottomans' attack that kept the reign over the Balkans until the early nineteenth century. As a result, the initial state-formation process followed by the Balkan Wars and the two World Wars took place in multi-ethnic regions. During the Cold War period, the diversity of ideologies and political systems in the area was considerable: the Balkans was home to a capitalist western democracy (Greece), non-aligned socialist Yugoslavia, the states behind the Iron Curtain (Romania and 


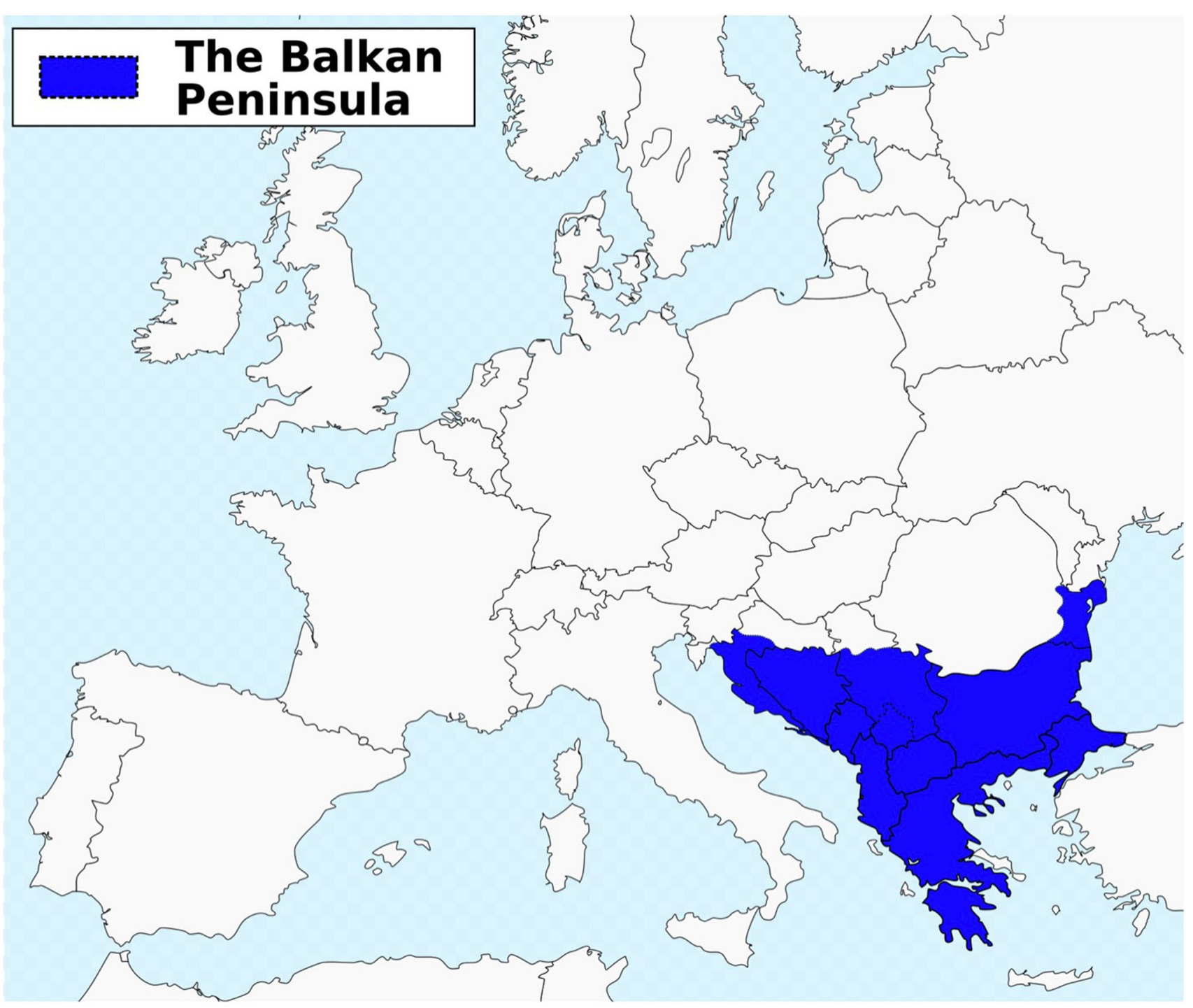

Fig. 1 The Balkan Peninsula in Europe. Copyright: ArnoldPlaton

Bulgaria), as well as the communist Albania influenced by China. The fall of the Berlin Wall together with the rise of nationalist tendencies in the federal states of Yugoslavia led to the dissolution of the country. However, the consequences were felt throughout the region highlighting again the ethnic factors. On the one hand, Greece saw the Former Yugoslav Republic of Macedonia as a historical, political and security threat, which was dissolved almost thirty years later when the new state name of North Macedonia was coined in 2019. On the other hand, the position of the Albanians living in the diverse parts of former Yugoslavia and Greece was strongly affected as they gained political significance.

The current political and territorial dispute still relates mainly to the unresolved issue of Kosovo and its selfdeclared independence from Serbia in 2008. Since it is not only a problem of regional and European importance, but also of global interest, its resolution, together with NATO membership, determines the pace and conditions for Serbia and other Western Balkan countries to join the European Union (EU). As the Balkans constantly suffers from internal social, political and economic problems, it is not considered a priority for EU funding (Acebillo 2015; Peric and Niedermaier 2019; Peric and Scholl 2017; Evmolpidis 2016; Vourdas 2016). However, China under the Belt and Road Initiative, but also Russia, Turkey and the United Arab Emirates consider the Balkans as a strategic destination of geopolitical significance, and, accordingly, invest in a number of ports (Piraeus, Thessaloniki), railway lines (BarBelgrade, Sarajevo-Belgrade, Belgrade-Budapest), energy facilities, and urban redevelopment projects (Scholl et al. 2019). As facing weak national economic conditions, the Balkan countries usually have no other choice but to adopt 


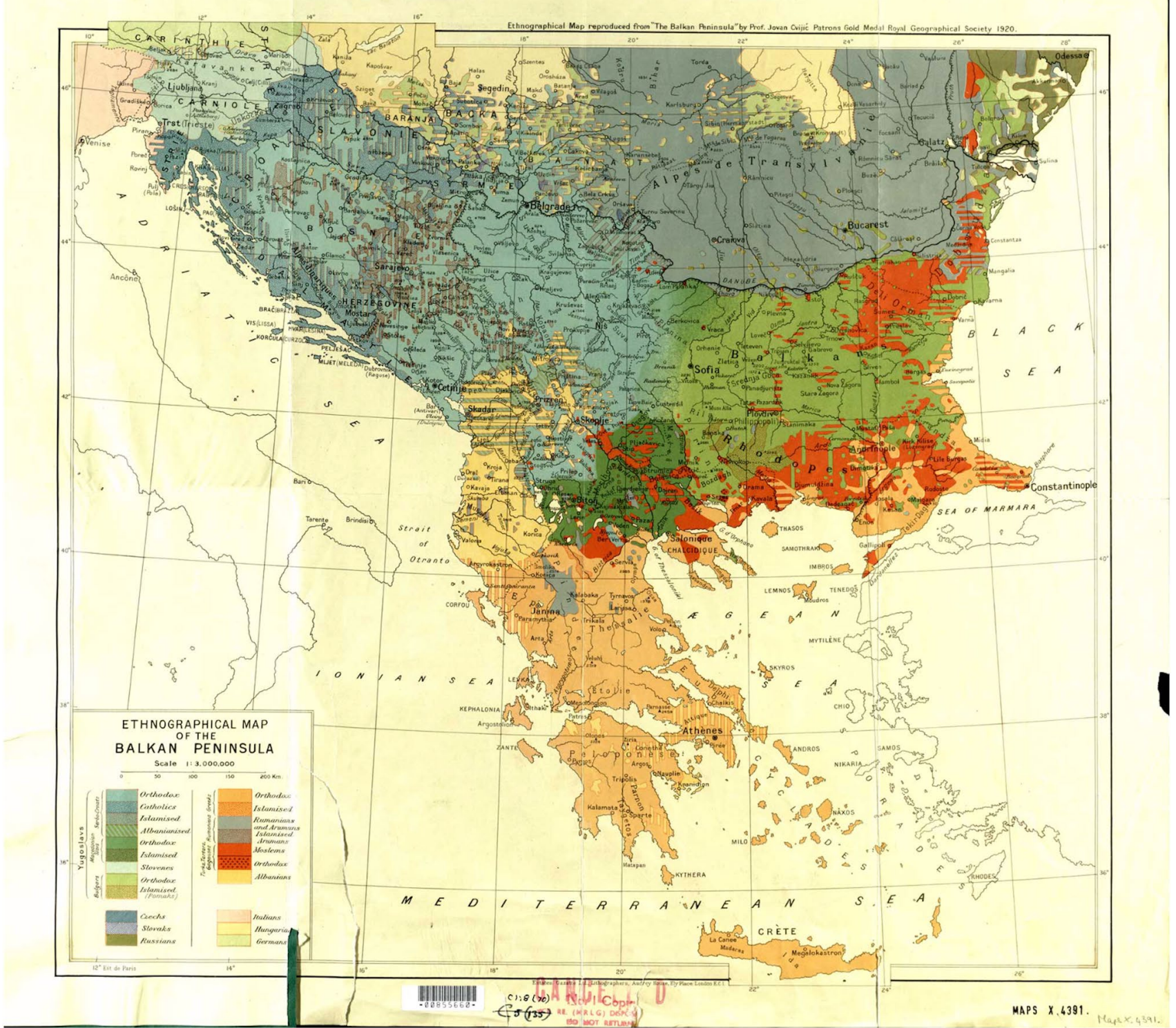

Fig. 2 Ethnographical map reproduced from The Balkan Peninsula by Jovan Cvijić. Source: La Péninsule balkanique. Géographie humaine, 1918. Copyright: British Library Imaging Services

the offers from foreign developers, consciously neglecting the domestic values (Cukic and Peric 2019).

Against the background of historical and current conflicts, it is rather a challenging task to achieve integration in the Balkans - integration amongst people, across territories and across ways of thinking and perceiving both problems and possible solutions. In addition to such a cacophony, permanent existential problems prevent wise territorial governance and management of both urban and rural areas, particularly in a collaborative manner that is considered standard for activities related to the development of the built environment and preservation of landscapes (Peric and Niedermaier 2019; D'hondt 2017; Mrdjenovic 2013, 2014). As a consequence, the territorial capital of the Balkan region is highly endangered.

A number of global and European polices that emerged over the last twenty years embrace the idea of making 'human settlements safe, inclusive, resilient and sustainable' as defined in the Sustainable Development Goal 11 (UN 2015). In addition to the 2030 Agenda for Sustainable Development (UN 2015), the New Urban Agenda (UN 2017) also promotes integrated spatial approach, recognizing the importance of: (1) cooperation between various bodies: national governments, local authorities, civil society, and planning professionals, and (2) planning for various levels: transnational, national, regional, city, municipal, 
and neighbourhood level. Urban Agenda for the EU (EC 2016) places an emphasis on the policy making based on the intrinsic contribution of citizens through various forms of urban governance that support public voices at different levels-from urban design projects to strategic master plans. Territorial Agenda of the European Union 2020 (EU Ministers 2011) clearly promotes, inter alia, cooperation between different spatial units by respecting the goals and principles amongst strategies at different scales: from those addressing the transnationally important topics, to national and regional priorities and local incentives. Green Paper on Territorial Cohesion (CEC 2008) in addressing European spatial and territorial development, ${ }^{1}$ promotes the following principles: functional territorial development, place-based approach, multi-level governance, multi-sectorial cooperation, and territorial integration. Finally, the European Spatial Development Perspective (CSD 1999) clearly prioritizes effective actor networks and efficient mechanisms for public participation, but also for involving all other parties in the common quest for balanced spatial development.

Following this line of argumentation, to strengthen territorial capital of the Balkans means to (1) substantially improve cooperation between the different jurisdictional/ territorial levels (e.g. national, regional, local) both in the policy making process and in practical implementation, and (2) to stimulate interactions between numerous actors - public administration, professional organizations, local and regional entrepreneurs, civic associations, i.e. those responsible for and affected by spatial transformation. Hence, this paper attempts to elucidate the concept of multi-level governance (MLG) and to illustrate its application to urban megaprojects. Since megaprojects are considered a spatial manifestation of neoliberalism, they are usually initiated by global actors with economic power, but to be properly deployed, they must be adapted to specific national and local conditions. This requests mutual adjustments between the global players and specific administrative rules, professional milieus and local identities. Empirically we examine a variety of actor networks in two major hubs in the Balkans - Belgrade and Athens. The capitals of Serbia and Greece, respectively, are selected as relevant cases as they currently host the largest urban developments in the Balkans initiated by supranational actors, and, consequently, are useful testbeds for exploring interrelationships amongst actors exercising power at various scales-dominant global developers, national governments in coalition with foreign investors at

\footnotetext{
1 The basic difference between spatial and territorial development can be briefly explained as follows: spatial development aims at a balanced growth of all the spatial units that form certain area, whilst territorial development promotes the further development of the areas with a high development capacity, i.e. not necessarily the least developed areas (Peric and Niedermaier 2019).
}

the expense of the public interest of their own countries, and professionals and citizens in an attempt to curb the negative effects of mentioned partnerships.

The paper is structured as follows. After introductory remarks, we examine the premises of MLG's approach to decision-making, emphasising in particular the relationships between different stakeholders from various sectors (public, but also private and civil) at the local (city) level. By attending to the planning traditions and planning cultures of Serbia and Greece, we tend to shed light on the planning contexts of the current megaprojects in Belgrade and Athens-the Belgrade Waterfront project and the Hellinikon project, respectively. The central part of the paper is devoted to the identification of local responses to global trends in urban development to recognize the main anomalies in both cases, as well as their mutual similarities and/or differences. Finally, we provide an overview of basic guidelines to avoid further spatial degradation in the Balkans.

\section{Multi-level territorial governance: a conceptual overview}

\section{The arguments for and against MLG}

Multi-level governance (MLG) is mainly seen as a result of the shift from government to governance throughout the 1980s (Rhodes 1996; Davoudi and Strange 2009). This shift "refers to the diminished role of governmental hierarchy, at the same time highlighting the stronger influence of nonstate actors who are mutually interdependent in a collaborative policy making process directed towards achieving common interests" (Peric 2019, p. 96). Accordingly, we differ two main dimension of MLG: the 'multi-level' dimension, which is focused on the relationships between various levels of public authorities-supranational, national and subnational; and the dimension of 'governance', addressing multi-stakeholder collaboration amongst the representatives of various sectors-public, private and civil (Bache and Flinders 2004; Böhme et al. 2015; Piattoni 2016). In other words, the MLG concept includes both the aspects of territorial hierarchy and functional unity.

However, implementing the principle of MLG in practice faces various problems (Faludi 2012; Piattoni 2016). Briefly, the nature of the dynamics is fuzzy, i.e.: (1) the engagement of certain governmental and non-governmental bodies is not clear enough, (2) networking amongst various sectors is not fully applied, but rather it assumes the cooperation between various jurisdictional scales, and, finally, (3) it is difficult to define the government level(s) that should be particularly active in governance processes.

Criticisms mentioned above point to specific territorial/administrative levels, i.e. the clarification of certain 
sectors and authorities, as well as their mutual relationships, which together contribute to the effectiveness of the MLG approach. This is, however, strongly influenced by the general need and reason for collaboration (Peric 2016). The dual character of the MLG concept-vertical cooperation amongst jurisdictional/territorial levels and horizontal cooperation aimed at functional unity, comes to the fore again. The ESPON's 'Rubikube' of MLG differs nine important 'levels of action' in the MLG process: supranational/EU, transnational, cross-border, national, interregional, regional, sub-regional, local, and sub-local levels (ESPON 2013). The following section briefly highlights different objectives, types and deliverables of the cooperation at the local territorial scale.

\section{The role of the local level in MLG}

The local level in the process of MLG gains great importance for several reasons (Peric 2019). Firstly, local stakeholders have a broad awareness of the majority of the problems, values, obstacles and opportunities that dominate the local situation (Böhme et al. 2015; Hooghe and Marks 2010). Secondly, a pragmatic and action-oriented approach at local level is easy to apply compared to some higher territorial and administrative scales (Scholl 2012). Accordingly, intrinsic features of a place that is shaped by the needs and visions of numerous actors, and is not only regulated by administrative bodies, are more apparent on a smaller territorial scale. Consequently, cooperation between different local stakeholders streamlines the implementation of certain measures (Böhme et al. 2015).

The main types of cooperation at the local level are: intersectoral and interdisciplinary cooperation. On the one hand, "the structured partnerships between policy makers, private sector and civil society are necessary to mobilize wider societal support for development" (Peric 2019, p. 101). As these sectors use different approaches to tackle complex problems (e.g. developers' profit versus public accountability), only well-structured collaboration can ensure the achievement of different interests without denying certain parties and their goals. On the other hand, "the synergy amongst different knowledge pools, skills, know-how and tools facilitates the governance process, thus, ultimately, contributing to the transformation of thinking patterns as the main outcome of the changed governance model at the local level" (Peric 2019, p. 101).

The interdependence between various sectors and disciplines requires forms of social learning across diverse webs of institutional and organizational action (Hooghe and Marks 2010). Considering not only the expertise, but also 'experiential' knowledge and skills, calls for a role of mediator and/ or facilitator of the MLG process (Bache and Flinders 2004; Davoudi and Strange 2009). When applying this process to the field of urban development, the facilitator's role is usually devoted to planning professionals. In better anticipation and preparation for current and plausible problems, planners should "be acquainted with the context where they operate, capable of constant capacity-building, able of conducting socially justified activities and, thus, producing sustainable spatial solutions" (Peric and Hoch 2017, p. 1251).

In sum, the MLG process in an urban development project, i.e. at local/urban/city level, emphasizes the governance aspect more than vertical cooperation between different authorities. Such an approach requires constructive cooperation between different sectors to achieve consensus-building and to arrive at solutions that are acceptable to all interested parties (Le Gales 1998; Brenner 2004; Bache and Flinders 2004). Accordingly, the roles of the relevant actors are defined as follows:

(1) The private sector as the initiator of urban development is valued because the ultimate goal is the functional unity, i.e. the agreement between stakeholders on a common vision for future development;

(2) The public authorities are responsible for providing the necessary institutional and regulatory support to implement the development idea;

(3) Experts are important actors as they enable the whole process to be as transparent, efficient and effective as possible;

(4) The civil sector is seen as a corrective factor in case that development leads to socio-spatial distortions.

The assumed assignments and role of various stakeholders in an urban governance process speak for boosting the capacity to organize collective actions aimed at building partnerships directed towards specific goals. Such an approach found a particular relevance for solving complex problems. Hence, urban megaprojects associated with dynamic and complex relationships between different stakeholders provide a fertile ground for exploring the MLG concept in urban planning practice.

\section{Methodology: exploring urban megaprojects in the Balkans}

Urban megaprojects require functional unity around a spatial problem such as: lack of infrastructure for basic services, obsolete transport infrastructure, or dilapidated superstructure in central or exclusive districts like waterfronts (Swyngedouw et al. 2002). Since public funding is usually insufficient to cover (re)development costs, global economic actors (banks, funds, private consortia) come to the fore (Flyvbjerg 2014). Consequently, they require less informal, but more intense horizontal cooperation amongst stakeholders at the 
local level without strong control by public authorities at higher administrative levels (Brenner 2004). Nevertheless, entrepreneurial spirit and political support offered at national scale are a necessary prerequisite for international developers to pursue megaprojects (Brenner 2004; del Cerro Santamaria 2013). Briefly put, the 'iron-law of megaprojects' (Flyvbjerg 2017), which is based on the logic of exception, e.g. extra budget, special regulations, non-standard organizational structure, questioning of public accountability, and the central role of developers at the expense of the city leaders, planners and citizens, makes urban megaprojects an interesting case for exploring the principles of MLG, as described in the previous section.

Although it is generally accepted that the planning, governance and implementation of megaprojects is quite similar regardless of the context - developed Global North or developing Global South (del Cerro Santamaria 2013; Lee 2012; Flyvbjerg 2009), there are some variations in the implementation of megaprojects in 'sensitive' societies, e.g. in transitional, post-socialist countries or countries facing economic downturn.

The boost of global economy makes urban megaprojects an attractive model for the development of urban patterns in post-socialist states faced with political, institutional and market transition (Cook 2010; Cope 2015; Zekovic et al. 2018). However, as the key drive behind any urban megaproject is extra-profit for its developers, megaprojects in the context of wild neoliberalism clearly point to "social distortions caused by the superior position of the private sector, opportunism within government structures, lack of professional expertise and, finally, neglect of the public interest" (Peric 2020a, p. 213). Urban megaprojects are also a popular means of addressing urban development in societies with defaulted economies (Prentou 2012; Papaioannou and Nikolakopoulou 2016; Zifou 2015). In order to overcome the economic downturn, national governments neglect the social and environmental aspects of territorial capital and instead focus on space only as a tool for economic growth. Consequently, privatisation and deregulation become the main strategy for the megaproject development (Komninos 2014).

With previous in mind, we want to elucidate the local feedback to a global trend of megaproject development in Serbia and Greece as the societies burdened with internal tensions in addition to supranational challenges. Particularly, we look at the Belgrade Waterfront project in Belgrade and the Hellinikon project in Athens as the cases that blend very well with the logic of exception ingrained in the urban megaproject development. More precisely, we apply the MLG conceptual framework as previously described to elucidate the following variables: the nature of incentives of private developers (e.g. functional, i.e. directed to profit only and/or of exercising political influence); the response of the state public authorities (e.g. reactive, i.e. fully supportive to the investors' demands and/or proactive, i.e. enabling the setting for addressing both private and public interests); the position of planners towards the partnerships between investors and public authorities; and, the level of public engagement as a response to the main coalitions in urban megaproject development.

To collect the relevant data, we use the insight into various documents. Notably, the triangulation approach in data generation helps to obtain as objective as possible understanding about the ongoing urban development in Belgrade and Athens. More precisely, we collect (1) official documentation (national laws, plans, strategies, regulations, and contracts) that depict the position of the state authorities towards megaproject development, (2) secondary sources, i.e. the scholarly articles on the current urban development in Serbia and Greece that provide a critical perspective on the current urban practices, and (3) newsletter articles and media announcements, which illustrate the general narrative behind the implementation of the selected cases.

Accordingly, to analyse the obtained data, we apply: (1) the documentary analysis of primary sources, to elucidate critical relationships between the foreign developers' incentives and the national governments' responses to them, (2) the content analysis of scholarly articles on the current developmental challenges, to identify the professional position to current development trends and the nature of citizen engagement in the public issues with considerable spatial impact, and (3) the discourse analysis of the newspaper articles and media announcements, to unveil the nature of communication channels about megaproject trends.

\section{The Balkans' urban megaprojects: cases from Serbia and Greece}

\section{Serbia: the socio-spatial setting under a 'proto-democracy'}

The transition of Serbia towards neoliberal society is slow and full of various obstacles. The political dictatorship ended in 2000, however, a political culture based on rudimentary pluralism, together with a low level of administrative and financial decentralization (Peric 2020a), makes the Serbian society a 'proto-democracy' even today (Vujosevic 2010). Moreover, the lack of political and institutional reforms, as well as adequate strategy, measures, and mechanisms towards a market economy has led to a chaotic situation in which only Serbian and foreign oligarchs have been able to assert their interests (NedovicBudic et al. 2012). Professional expertise is still shaped by the principles of comprehensive planning and as such shows neither affection for the needs of the free market in the area of spatial development (Nedovic-Budic and 
Cavric 2006; Vujosevic and Nedovic-Budic 2006), nor for the necessity for collaborative planning introduced by informal strategic planning with the involvement of large (foreign) funds such as UN-Habitat and the Deutshe Gesselschaft fur Internationale Zusammenarbeit (GIZ) (Lazarevic-Bajec 2009; Peric and Miljus 2017). Participatory mechanisms are still rarely used in planning practice, whilst planners often show a great disinterest, mistrust, and fear of communicating with the public (Maricic et al. 2018). As a consequence, citizens are usually not included in any kind of decision-making, hence, acting as passive observers of the ongoing spatial transformation (Cvetinovic et al. 2017). Only grassroots movements appear to perform as advocates of the public interest (Grubbauer and Camprag 2019).

\section{The Belgrade Waterfront project, Belgrade}

Through history, the development of the Belgrade waterfront area has always received a great attention from urban professionals, politicians, and citizens (Peric 2020a; Kovacevic 2014; Grubbauer and Camprag 2019). The idea to create the new urban centre of Belgrade on the right bank of the Sava River dates back to the first master plan of Belgrade of 1923. Its potential was further analysed in numerous academic studies and urban design competitions throughout 1970s and 1980s, e.g. the Home of Friendship (1975) (Fig. 3), and the Town on Water (1990) (Fig. 4). Even in time of an immense economic crisis in the 1990s, the project Europolis (1995) was considered a flagship project. Since the beginning of the new millennium, the 90-ha area has been continuously deteriorating to, finally, transform into a huge brownfield area in the Belgrade urban core occupied mainly by an old shunting yard as part of the Belgrade main railway station and some dilapidated housing.

The Belgrade Waterfront (BW) project was announced during the 2012 political campaign of the then largest opposition party. After winning the elections, the party fulfilled its promise: the construction of a grand political project financed by the United Arab Emirates (UAE) investor, Eagle Hills, with considerable subsidies by the Serbian government, commenced in September 2015. The preliminary design project by SOM (Skidmore, Owings \& Merrill) served as a base for the final project design by the local planning and architectural offices (Fig. 5), to comprise an area for over 6,000 flats ( 1 million $\mathrm{m}^{2}$ ) with 20,000 inhabitants, but also numerous commercial and cultural activities, a huge park, a new shopping centre, and a hotel, which at $210 \mathrm{~m}$ will be the highest building in the Balkans (Radojevic 2017). The construction costs are estimated at 3.1 to 8 billion euros, with the timeframe for completion of the project including the three phases being 2045 (Eagle Hills 2015).
Belgrade Waterfront: urban development under hybrid democracy

To elucidate the process that led to the implementation of the Belgrade Waterfront project in September 2015, the following lines describe specifically the positions and interrelations amongst various stakeholders, namely: Eagle Hills as developer, the Serbian government and the City of Belgrade, Urban Planning Institute and the Republic Agency for Spatial Planning as planning professionals, and NGOs 'Don't let Belgrade d(r)own' and the 'Ministry of Space', as representatives of the civil sector.

Developers. The Abu Dhabi-based company Eagle Hills invests mainly in the Middle East, but also in Ethiopia, Morocco, Jordan, and Serbia (Radojevic 2017). Selected upon direct negotiations with the Serbian government, i.e. without international bidding, Eagle Hills got numerous subventions to invest in BW. In addition to the environmental restoration, the removal of obsolete infrastructure, and the provision of the new one, the state is obliged to lease the land to the developer for 99 years (OG RS 3/2013). Notably, the latter excludes any fee for Eagle Hills whilst: (1) leasing the land; (2) getting the right of land ownership once the building stock is constructed and a month after a use-permit is obtained; and (3) transferring the right of land ownership to other parties. Practically, the land is given for free to foreign developers.

Public sector. The cooperation between the Government of United Arab Emirates and the Government of the Republic of Serbia was legally approved as a basis for the development of the BW project (OG RS 3/2013). The power relations amongst the two are, however, not balanced as the mentioned law obliged Serbia to approve all amendments to any other legislative act in the manner desirable for the foreign investor. To illustrate this, the Lex Specialis - Act on Establishing the Public Interest and Special Procedures of Expropriation and the Issuance of Building Permit for the Project Belgrade Waterfront (OG RS 34/2015) was adopted although certain directives transposing the law were missing (Maruna 2015; Zekovic et al. 2018). Such a legal irregularity provides a room for different malversations infringing the public interest. In addition, solely the high-level politics is in charge of strategic decision-making - e.g. the main initiator of the project was the then-prime minister, today (2020) the process is led by the president. The situation is further complicated by the fact that both functions are embodied in the same person.

Planning professionals. The plan making procedure involved only two domestic institutions. The urban planning office of the City of Belgrade - Urban Planning Institute, created the Belgrade Waterfront Concept Masterplan in July 2014 based on the design project by SOM (Cukic and Peric 2019). This step is at odds with a routine planning 


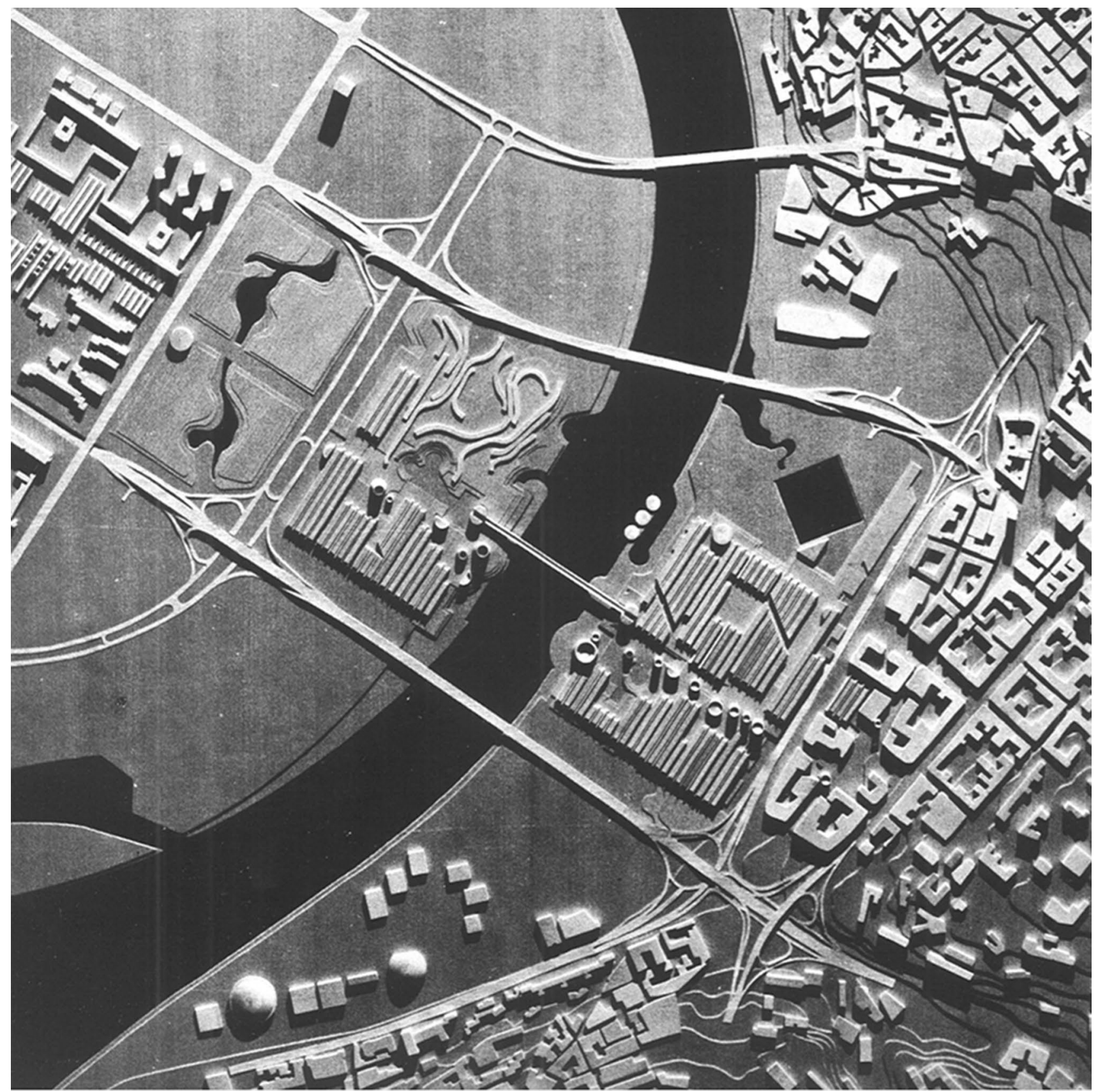

Fig. 3 The home of friendship. Source: 70 Years of Urban Planning Institute of Belgrade-Book II: Plans. 2018. Copyright: Urban Planning Institute of Belgrade

procedure, where a plan covers all the provisions necessary for the design of a project (Kovacevic 2014). In addition, the BW Concept Masterplan strongly differs to the nature of the Belgrade master plan (Zekovic et al. 2018), and, consequently, in September 2014, it was just ex post added as Amendments to the Master Plan of Belgrade (OG CB 70/2014). According to the procedural regulations, to implement high-tier urban plans means to produce a series of second-tier regulatory plans, approved in a round of debates by the planning commissions and the public. To avoid this, the Government decided to introduce the specific spatial plan, ${ }^{2}$ as a higher tier document demanding less coordination on the local level (Kovacevic 2014). This plan was prepared

2 According to Serbian nomenclature of plans, the spatial plans are prepared for: (1) republic, (2) regions, (3) city/municipality, and (4) non-urban areas of particular importance-mining and coal seams, flooding areas, natural resorts, etc. The spatial plan for BW was assigned to the latter category. 


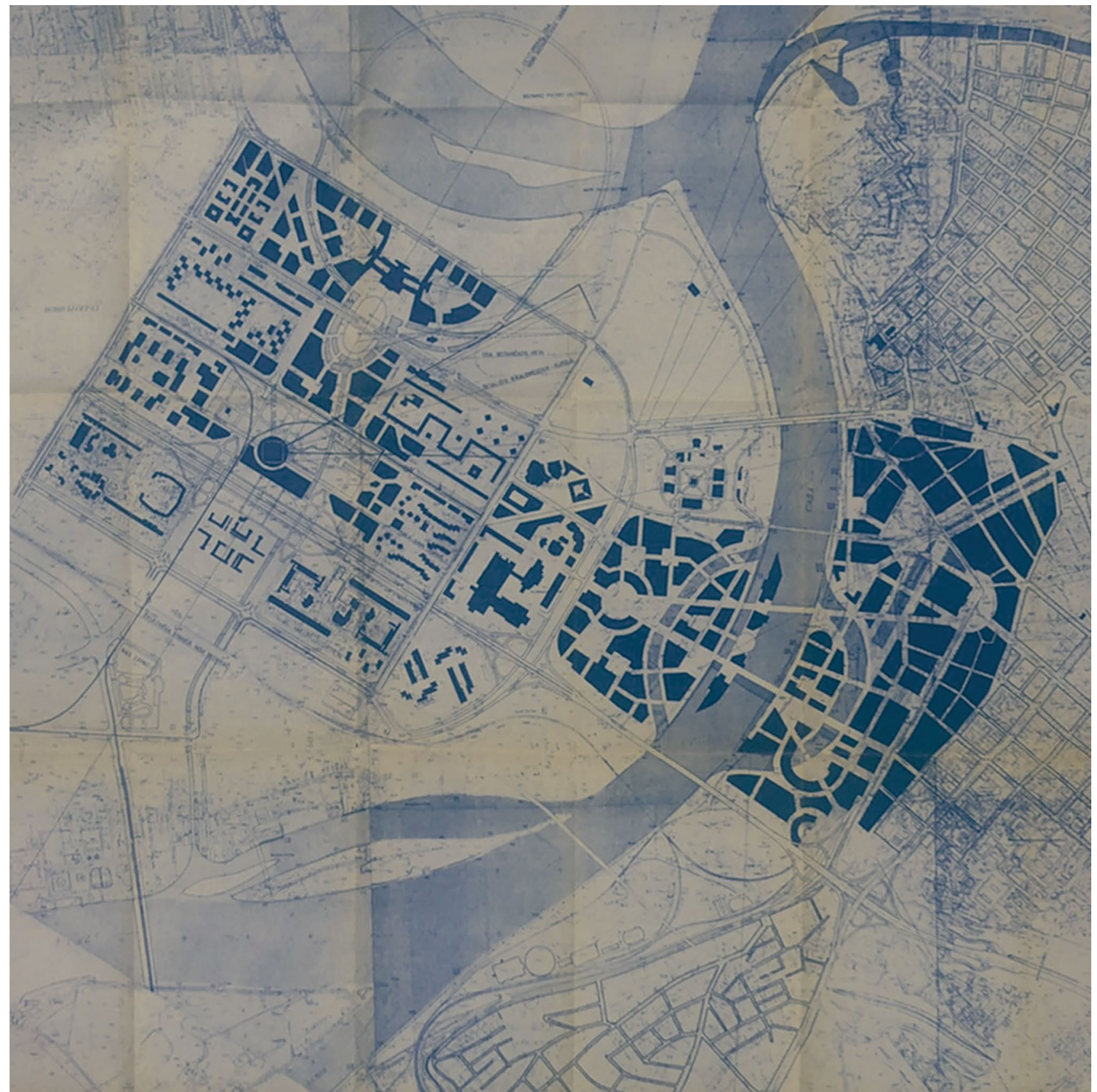

Fig. 4 The town on water. Source: 70 Years of Urban Planning Institute of Belgrade—Book II: Plans. 2018. Copyright: Urban Planning Institute of Belgrade

by the Republic Agency for Spatial Planning (RASP) in full accordance to the BW Masterplan. However, the planning law from December 2014 (OG RS 132/14) revoked the RASP and appointed the Serbian Ministry of Construction, Transport and Infrastructure as a body in charge of the further plan development. The spatial plan of Belgrade Waterfront (OG RS 7/2015) was adopted in January 2015.

Civil sector. Represented by two NGOs, the civil sector organized a range of activities usually following the governmental decisions beneficial for Eagle Hills. As a reaction to the proposed amendments to the Master Plan of Belgrade, the citizens of Belgrade made over 3000 complaints, whilst more than 200 people actively participated in the public insight pointing out all kinds of irregularities proposed by the master plan amendments. Although the session lasted for more than six hours, all of the complaints were rejected, or only superficially taken into consideration, and the Amendments to the Master Plan of Belgrade (OG 


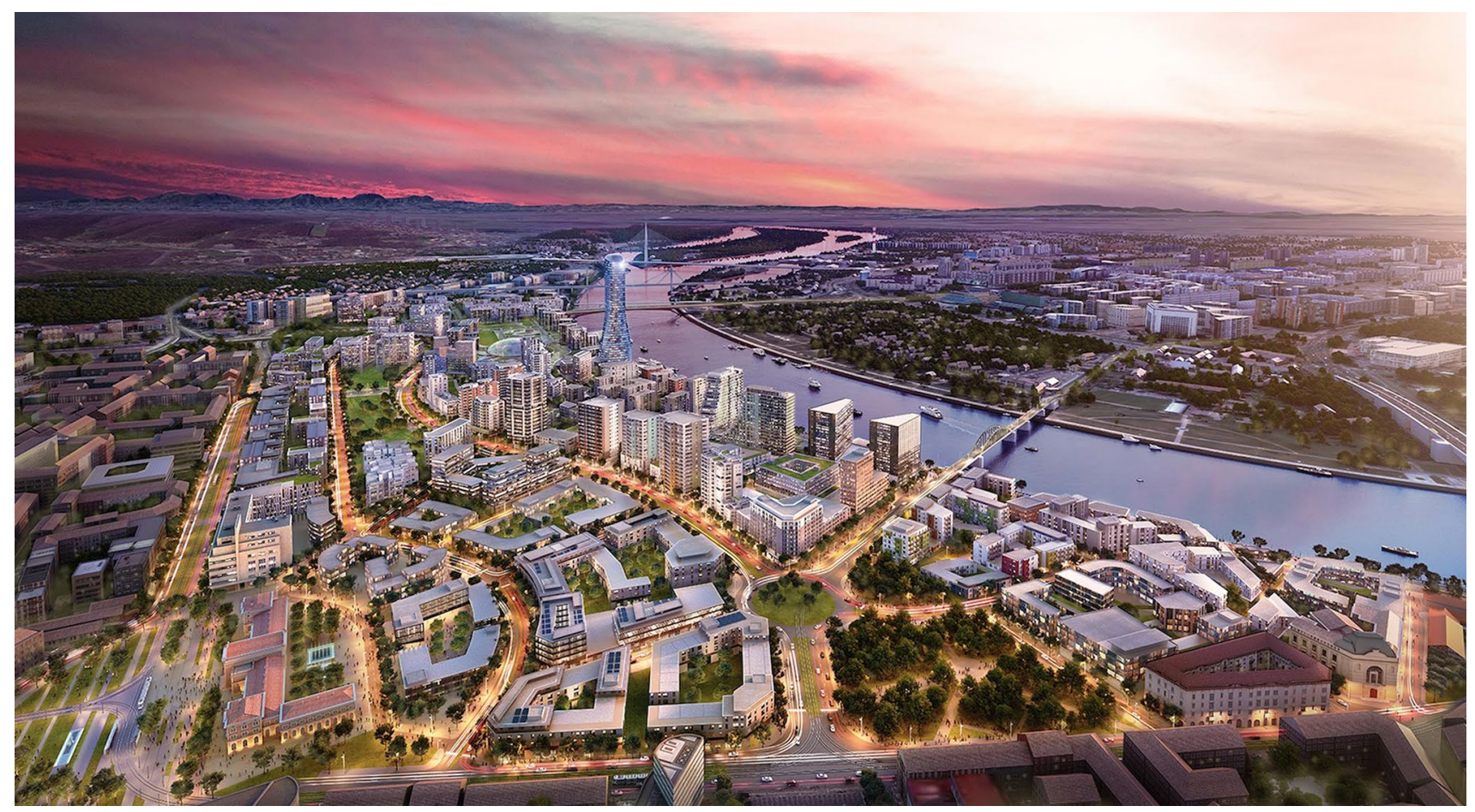

Fig. 5 Belgrade Waterfront-a model. Source: www.belgradewaterfront.com. Copyright: Eagle Hills

CB 70/2014) were verified in September 2014 (Cukic et al. 2015; Peric 2020b). Despite this, the civil sector continued with public discussions. Through the open debate with academics "What is hidden beneath the surface of the "Belgrade Waterfront" in October 2014 parallelly to the spatial plan making procedure and the creative performance "Operation lifebelt" in November 2014 during the public meeting on the approval of the Plan for the Area of Specific Use, the activists tried to attend to the shortcomings as presented in the plan. Again, the political structures embodied in the planning commission stayed 'deaf' to the citizens' calls resulting in the adoption of the preliminary version of the spatial plan two months later, thus excluding all public remarks (Cukic and Peric 2019; Peric 2020b). Even after the start of construction of the BW project in September 2015, citizens regularly organized the protests in 2016 and 2017. The public revolt, however, did not prevent the further development of the area. Currently (2020), several housing objects, a shopping mall, a great deal of road infrastructure and public open spaces have been finalized and open for public.

\section{Greece: the socio-spatial setting under the economic downturn}

Greece was severely challenged by the downturn on the international financial markets in 2008/2009, which generated a prolonged economic crisis. A major state-funded recapitalisation of the financial system aimed at boosting economic growth and reducing unemployment (Hadjimichalis 2011). However, Greek excessive private debt forced emergency measures in support of private real estate investments (Prentou 2012). These investments appeared to be speculative, i.e. highlighting the benefits of proposals from lenders and developers associated with high-level politicians, but highly opaque and made without involvement of public officials (Papaioannou and Nikolakopoulou 2016). For example, the Hellenic Republic Asset Development Fund (HRADF) in fact serves to pursue the push towards privatisation of public land and assets by transferring the responsibility of many services and public agencies into private entities (Prentou 2012; Peric and Hoch 2017). Local planning officials, however, stay connected to the urbanism planning tradition, thus, considering planning as blueprint plan making instead of creating the guidelines to effectively manage a planning process as a complex activity involving numerous actors. Even worse, some apply corruptible measures to authorize often illegal urban growth (Getimis and Giannakourou 2014). On top of this, despite the decentralization of spatial planning in the 1990s, aimed at giving more responsibility to lower-tier public bodies (municipal and regional authorities), public engagement as part of link between local institutions and the local people remains weak (Giannakourou 2011). The planning practice is dominated by "the bureaucratic administrative culture, encouraging reliance on narrow disciplinary expertise unable and unwilling to cope with the increasingly complex spatial problems" 


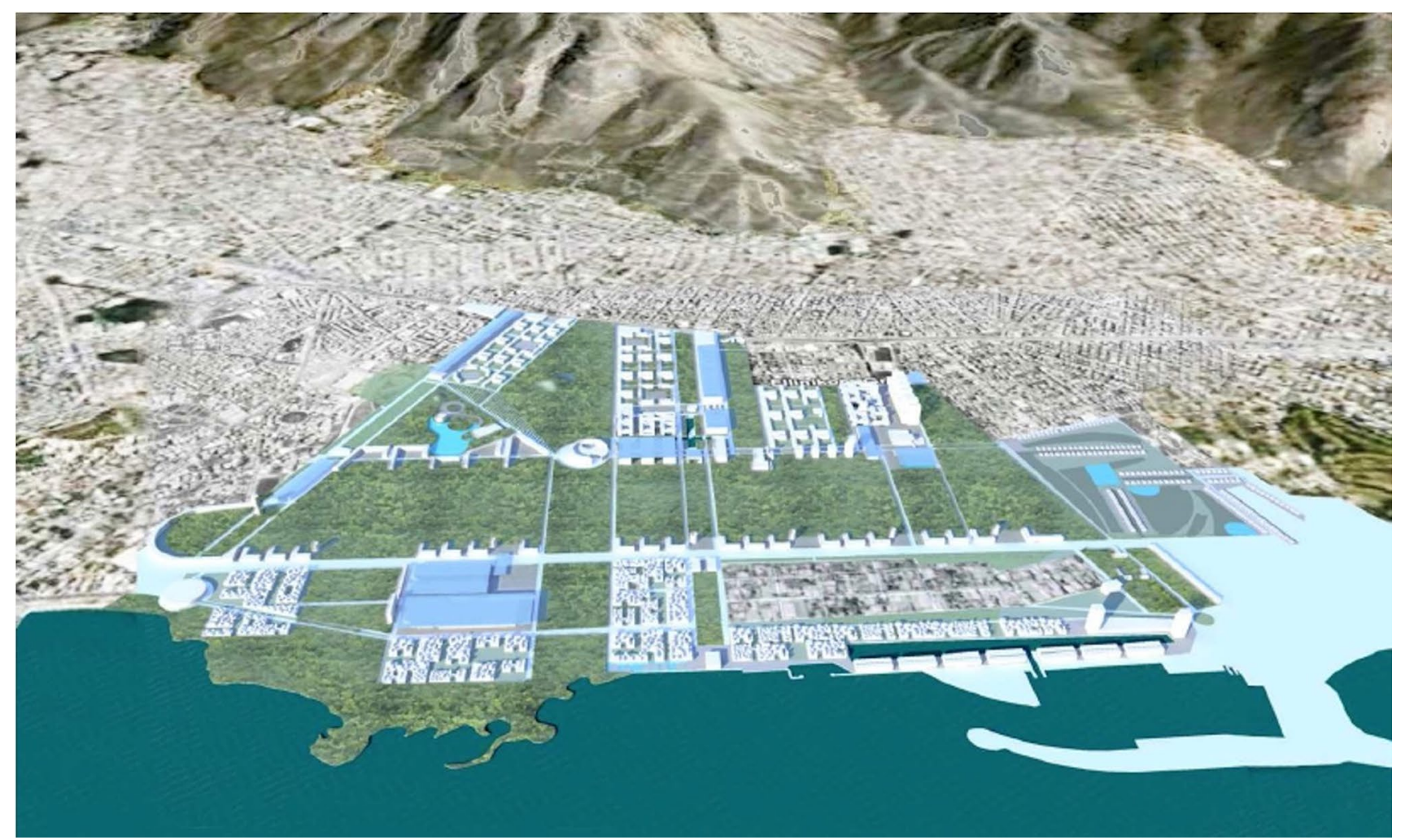

Fig. 6 Hellinikon strategic urban model. Source: Hellinikon Strategic Urban Model: New Urban Centrality for Innovation, 2011. Copyright: Josep Acebillo / BcnSuS

(Pappas cited in Papamichail and Peric 2018, p. 335). As a result, professionals cannot do much to restrict close feedback between developers and politicians, hence, repeatedly posing crises for effective spatial development (Papamichail and Peric 2018; Komninos 2014; Zifou 2015).

\section{The Hellinikon project, Athens}

Since its opening in 1938, the Hellinikon airport has always been an important strategic area for both Greeks and internationals (Milionis 2010; Prentou 2012; Komninos 2014; Pollalis 2012). In the period of its full operation, it served as the main Greek airport, whilst partly also as a US military base (1953-1991). At its waterfront nearby, the Agios Kosmas National Youth Centre was opened in 1961. Situated only $10 \mathrm{~km}$ south from the Athens downtown, the airport was constantly upgraded to reach its critical capacity in the 1990s. After the decision to build the new Athens airport in Spata in 1995, the Hellinikon airport was officially closed in 2001. For the 2004 Olympic Games, the former airport and a coastal front line hosted a number of sports. Between 1995 and 2011, the national and local (both metropolitan and municipality) governments financed a number of competitions and studies to explore the possibilities of future development of the area. The proposals presented in 2011 are: the Hellinikon Strategic Urban Model (Fig. 6), and the Metropolitan Green Park (Fig. 7), revolving around a lowcost-low-revenue strategy for social and environmental benefit of Athenians, as well as more economically viable solutions like the Hellinikon Urban Development Model (Fig. 8).

The first idea towards privatisation, attracting developers and making profit out of the Hellinikon redevelopment-measuring a total area of $626 \mathrm{ha}, 528$ ha of the former airport and 98 ha of the coastal zone-appeared soon after the economic crisis hit (Komninos 2014; Prentou 2012). The negotiations first started with the Qatar government in 2010, but the European competition regulations forced the Greek government to open a call for investments with accompanying institutions and regulations: in May 2011, Hellinikon SA (a société anonyme) was established in charge of administration, management, and exploitation of the land and facilities of the Hellinikon area (Pollalis 2012), whilst two months later the law enlisted the area as the state-owned asset ready for privatisation (Prentou 2012). After shortlisting four investors in 2012, Lamda, a Greek consortium with international shareholders, was finally chosen in November 2014, with a deadline for the acquisition of $100 \%$ of the share capital of Hellinikon SA set for November 2016 (The Hellinikon Project 2020). This is still pending as the regime of leftist Syriza 


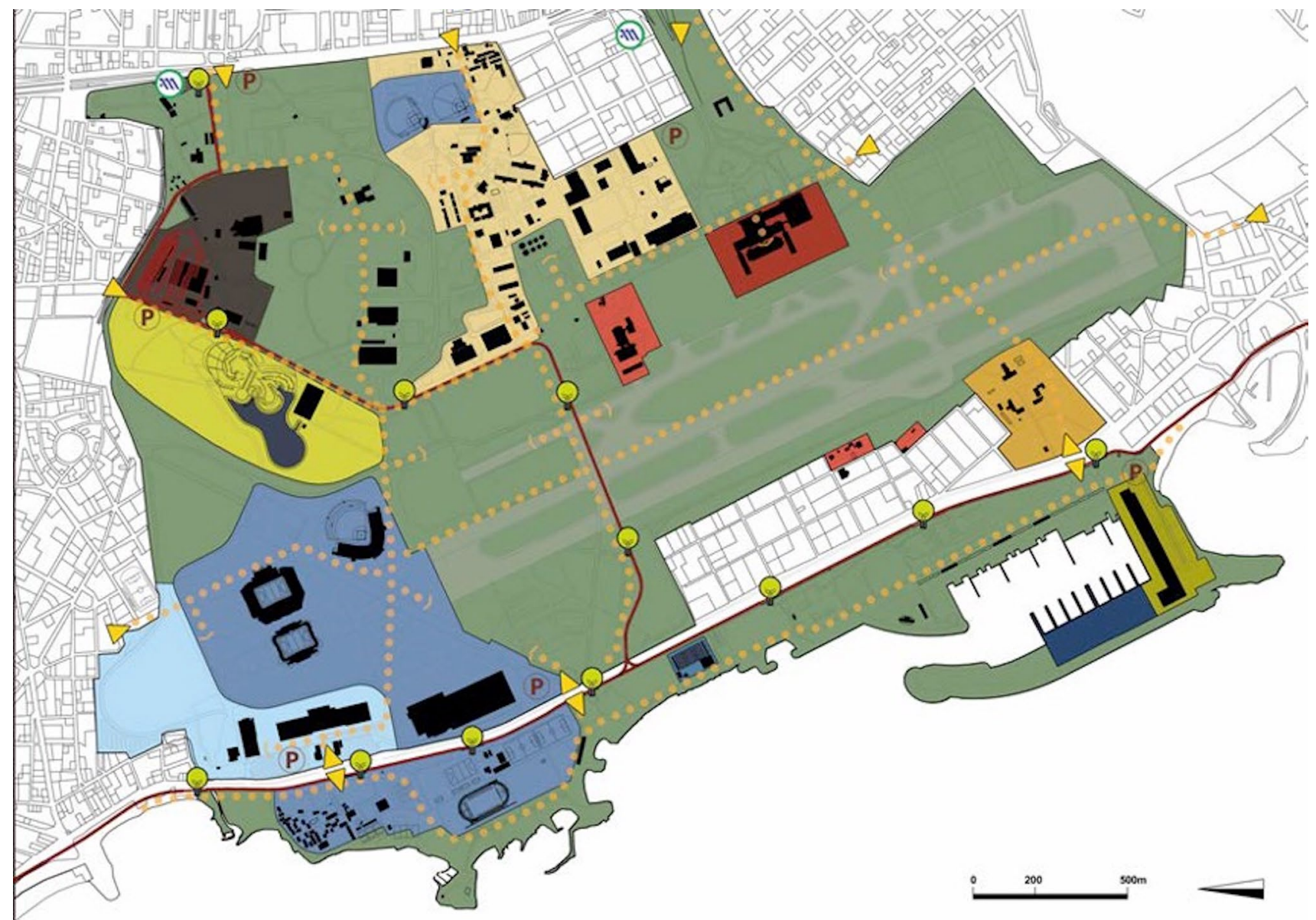

Fig. 7 General master plan of Hellinikon Metropolitan Green Park. Source: Basic planning \& design principles for the creation of the Metropolitan Green Park at the former Hellinikon International Airport of Athens, 2010. Copyright: NTUA Urban Environment Lab

(2015-2019) prevented foreign businesses from operating in Greece; nevertheless, immediately after centre-rightist New Democracy won the elections in July 2019, the new prime minister promised to accelerate the Hellinikon development (National Herald 2019; Kampouris 2019). In a meantime, Lamda engaged Foster and Partners to provide a design for the future 'new city' within the Athens metropolitan area, comprising business, retail, and residential districts, art venues, a metropolitan park of 200 ha, and a revitalised public coastline of $3.5 \mathrm{~km}$ (Fig. 9). The area will host 40,000 residents and generate 75,000 jobs. The total costs are foreseen to 8 billion euros, with the implementation period set to 2045 (The Hellinikon Project 2020).

\section{Hellinikon: economic prosperity for whom?}

To present a brief overview and emphasize the most important steps and decisions in the process of the Hellinikon development, the networks amongst the following actors are described: Lamda, the developer, Hellenikon SA and HRADF, as local and national public negotiators, the National Technical University of Athens (NTUA) and delegation of the Association of Greek Architects and Panhellenic Union of Architects (SADAS-PEA), as both academic and professional experts, respectively, and the Initiative for the Hellinikon Metropolitan Park, as the civil sector representative.

Developers. The law prescribing the future development of the Hellinikon (OG RG 4062/2012) allows the developer to create a mixed-use development without any restrictions regarding land uses, with the exception of manufacturing (Prentou 2012). On the contrary, the Greek state obliged to demolish the buildings already on site, allow blockade of the free access to the coast if needed, construct new infrastructure to and on site, and evict a number of organizations located in the facilities within the area (Municipality of Hellinikon-Argyroupoli 2013). After a bidding process, in 2014 the agreement was made with the Athens-based company Lamda, with an international consortium of shareholders like Chinese Fosun and the UAE Eagle Hills, for the purchase price of 915 million euros (The Hellinikon Project 


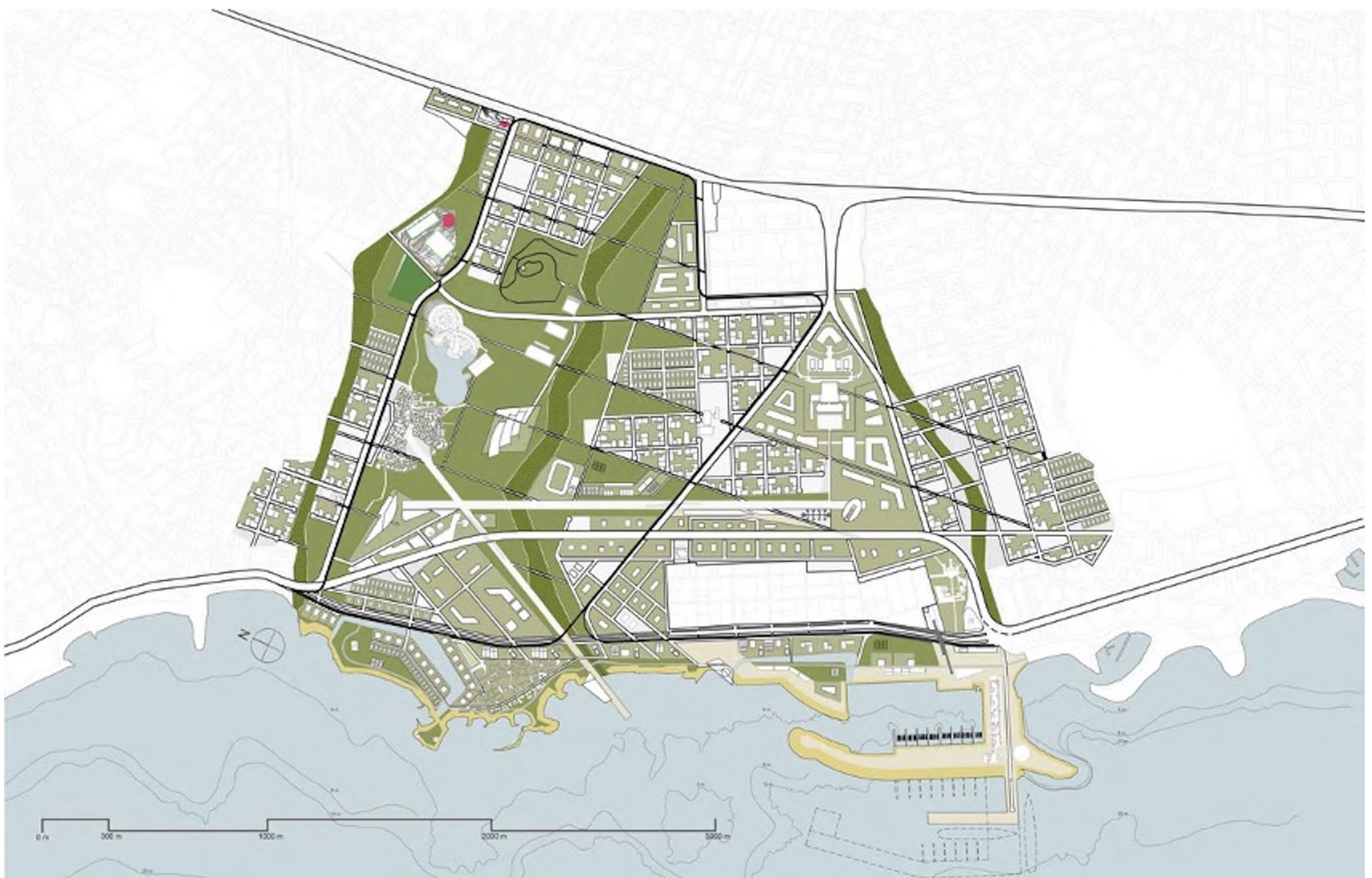

Fig. 8 Masterplan—urban development model. Source: Hellinikon Urban Development Model: Former Athens Airport \& Agios Kosmas Coast, 2011. Copyright: Hellinikon SA

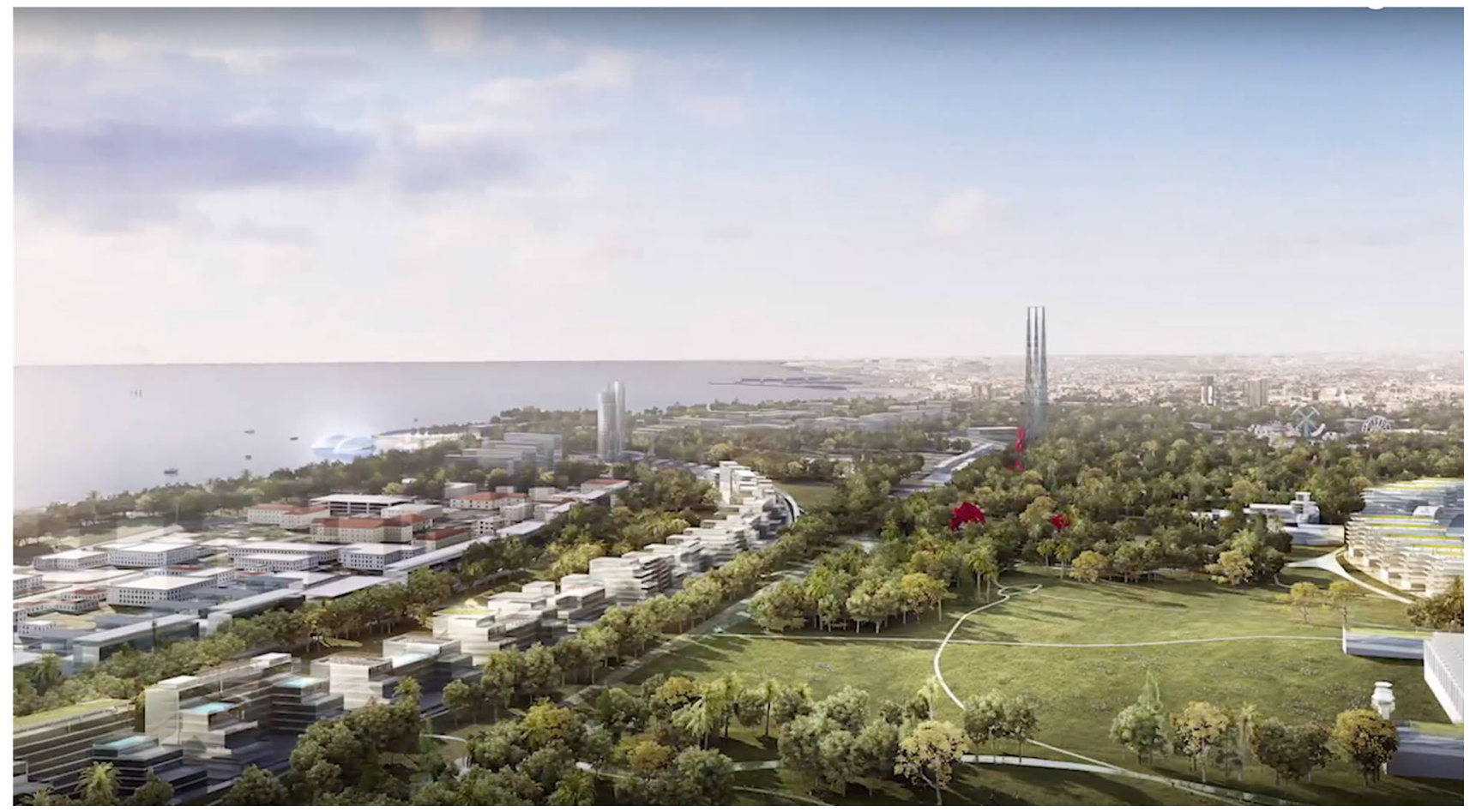

Fig. 9 The model of the Hellinikon project. Source: www.thehellinikon.com. Copyright: Lamda 我 
2020). The contract for the future development was ratified by the Greek Parliament in 2016 after a series of modifications toward more green, open and public areas, and a socially responsible development, as demanded by the thenprime minister (Kampouris 2019). This document was, nevertheless, subject to a number of administrative adjustments, so the final contractual preconditions have been approved by means of Joint Ministerial decisions just in late 2019 (The Hellinikon Project 2020).

Public sector. The positions of public sector towards developer's vision were changing depending on the political profile of the ruling parties. In 2010, it was the Greek government that initiated idea on the Hellinikon redevelopment. Following the directives from the International Monetary Fund, the European Union, and the European Central Bank, in 2011 the HRADF was established to negotiate with international bidders (Prentou 2012), whilst the mentioned law 4062/2012 was amongst those following "a fast track approval process under the direct responsibility of the prime minister's office" (Karadimitriou and Pagonis 2019, p. 1227). By placing the debate about the Hellinikon redevelopment on the highest administrative level, Greece showed its commitment to pursuing privatisation as a desirable way to reduce national debt. However, the change of the regime brought important changes in terms of limiting the extraordinary benefits for developer, and instead focusing on broader social values. In the last five years, the collaboration between the highest administrative structures shifted to the local level-including local municipalities, regional authorities, archaeological councils, numerous ministries, professionals, and civic organizations (Kampouris 2019). The new government is determined to speed up the process (National Herald 2019).

Planning professionals. Since the very first ideas on the Hellinikon redevelopment, there was always a tension between mostly internationally renowned experts, who were invited to promote the privatisation strategy, and domestic planners and architects focused on the local needs, values and identities (Komninos 2014; Pollalis 2012). Among the latter, particularly inventive was academia, e.g. the NTUA Urban Environment Lab's proposal from 2010 envisioned a public metropolitan park, with scarce recreational, cultural, and research activities, focused on the social needs and environment protection (Prentou 2012). However, the law that served as a base for the development bids (OG RG 4062/2012) neglected the broader values as well as provisions for the long-term sustainability effects of a concrete project. As a consequence, the delegation of the SADASPEA immediately issued an appeal against the law, against the transfer of the area to the HRADF and, finally, against the sale of the area (Prentou 2012). In the following years, professionals and public authorities tried to jointly safeguard the public interest. However, even left-wing Syriza, that toppled a longstanding dual-party political system, was not able or even not willing to 'correct' the neoliberal reform that was spurred by the 2008 financial crisis (D'hondt 2017).

Civil sector. The representatives of the civil sector were numerous, active and agile in organising different types of activities-from public debates, to open demonstrations (Prentou 2102; Milionis 2010; Komninos 2014). Before the narrative on the Hellinikon's privatisation became dominant in 2010, the local activities were mainly supported by local and regional authorities. Later on, the initiatives became more oriented towards the sustainable use of land at the same time bringing the issue to the city, and even international scale. For example, the Urban Farm, established in January 2011, focused on planting vegetables and fruits, organising courses and networking with related initiatives on a 0.3 ha-lot at the Hellinikon site. The largest movement was the Initiative for the Hellinikon Metropolitan Park, launched in March 2011, which gathered 76 local and regional initiatives to: sign the open letter against privatisation (March 2011); organize a festival (May-September 2011), including concerts, forum, beach party, free exhibition, and four discussions and round tables; engage more than 3000 residents and institutions from Athens to plant 1100 olive trees (March 2012); and, organize two protests in Athens against the privatisation process and against the law 4062/2012 (March-April 2012). Metropolitan Community Clinic and the Civil Aviation Museum were established on site in 2011, whilst during the recent migration crisis the area served as a refugee camp. The refugees were forcibly evicted to clear the way for redevelopment.

\section{Discussion: the 'iron-law of megaprojects' in fragile societies}

The Balkans' megaprojects both show the key features of urban megaproject development: long timeframe for project implementation, extreme budget, flexibility in land use and building regulations, opaque interrelations between the stakeholders involved, contested public liability, and developers as the main actors. However, some characteristics of such an exceptional megaproject approach are even more strongly emphasized in the fragile societies of Serbia and Greece. To elucidate the principles of MLG in the development of the urban megaprojects Belgrade Waterfront and Hellinikon, we critically address: (1) the multi-level component, i.e. vertical cooperation between public authorities, (2) the governance aspect, i.e. horizontal cooperation amongst leading stakeholders, (3) the role of intermediaries, addressing planning professionals, and (4) the public position towards megaproject development.

Megaprojects generally require strong and constant support from the city administration, and/or other local bodies, 
with the initial green-light from the national governments. In both BW and Hellinikon cases, however, the position of the national government dominates, i.e. the local level is forced to accept the high-level decisions without any concrete involvement of city officials in protecting their local needs. For example, the voice of the Mayor of Belgrade was only heard because he belonged to the same ruling political regime (Maruna 2015), whilst Hellinikon SA as a local facilitator was overtaken by the HRADF only half a year after its establishment. However, this power of national bodies is distorted when exposed to international influence: the Serbian government is far inferior to the UAE government, as is the Greek prime minister to the Lamda international consortium. Mechanisms such as the 'authoritarian entrepreneurialism' in the case of BW (Peric 2020a) and the 'capital urbanisation' of Hellinikon (Komninos 2014) indicate the withdrawal of a state from the protection of social values using space as a source of speculative economic growth. Moreover, contested democracies suffering from an economic downturn are incapable to provide a room for bottomup deliberation by the authorities. This makes the economically strong supranational bodies also politically superior in the development of numerous urban megaprojects in a certain country, whilst local entities are neglected.

The cooperation between numerous stakeholders, as presumed by the MLG's attribute of functional unity, is called into question in the Balkans' megaprojects. Namely, the cooperation between developers and national authorities on the one hand, and revolted citizens on the other, is highly polarised. For example, BW got the status of a project of national importance, even though the Serbian government does not initiate the project solely, but in a speculative partnership with foreign developers (OG RS 1/12). However, there is a great imbalance in economic turnover for both sides. Lex specialis (OG RS 34/2015) undoubtedly allows land expropriation for the commercial project only in the interest of Eagle Hills, whilst the national interest is declared as creating new workplaces and assigning the construction work to the Serbian subcontractors (Peric and Hoch 2017). Notably, pointing to such misuse of territorial capital has been interpreted as a direct attack on the state and its continued growth, severely hindering any kind of democratic public participation. Similarly, the law on the Hellinikon development (OG RG 4062/2012) allows flexibility in planning the area, clearly opening up a room for casinos, luxury hotels, condominiums, and shopping malls without this being of social, environmental and economic benefit to the Athens metropolitan area and its inhabitants. The popular narrative revolved around the 'national economic development' and 'the creation of thousands of new jobs' (Municipality of Hellinikon-Argyroupoli 2013). However, the opponents of such a development (e.g. Syriza) were accused of being in favour of prolonging the economic crisis and slowing down the recovery (Kampouris 2019).

As the MLG approach is based on a complex network of different stakeholders, the presence of experts open to the opinions of other stakeholders seems to be central to efficient facilitation in the process of urban megaproject development. Both case studies, however, show a neglect of experts (both public officials and academics) by political structures supported by the developers. The principle of cronyism dominates the planning practice in Serbia: the UPI leaders, responsible for making the BW Concept Masterplan, are close to the ruling political party, thus being dependent on and under high pressure from the ruling regime when making the planning documents. Similarly, the takeover of RASP by the Serbian Ministry of Construction, Transport and Infrastructure is another example of a weak professional position. Moreover, the tasks of plan preparation and its expert control executed by one and the same government body constitute a "direct conflict of interests, a centralization of power, and a lack of transparency in the BW process" (Peric 2020a, p. 224). In addition to such a dominant politization of urban planning, planners themselves prove incapable of understanding the pluralist social reality in which different interests shape urban development; instead, they continue to acknowledge the unitary public interest, whilst diminishing the importance of negotiations with other relevant parties. Politicians wisely recognize such a professional disadvantage and use it to reinforce their own close feedback with developers. Greek planners were more active: academics proposed solutions for creative land use that went beyond the mixed-use development aimed at economic benefits but neglecting social needs and environmental preservation, whilst professionals boldly pointed out a number of decisions that violated public interests. However, their demands were eventually neglected in the same way as in Serbia- 'starchitects' like SOM and Foster and Partners, engaged in BW and Hellinikon at the request of developers, prevailed over local experts and local needs.

In both cases, the civil sector plays a key role, both by engaging with the general public and by supporting planning professionals. The BW project generated the skilled and organized civil sector, which was the first and most persistent actor to designate a number of irregularities in the BW planning process. Public authorities, however, remained indifferent to its demands. The Hellinikon project shows an even greater commitment from the civil sector, which benefited from the creative use of the site, whilst project development stagnated. However, with the renewed discourse of slow economic recovery, new constellations between the national government and Lamda developers delegitimize the role of the civil sector and marginalize the public interest. All this simply represents the current spatial planning paradigm in fragile societies: ignorance of democratic decision-making 
and attracting investments for major redevelopment projects through ad hoc approaches (Zekovic et al. 2015; Komninos 2014).

\section{Concluding remarks}

The possibility of rapidly generating immense financial benefits exclusively for private developers makes urban megaprojects the cause of social distortion in societies facing wild neoliberalism and a declining economy. This is particularly evident in the following: instead of exercising control over market-oriented development, high-level representatives of the public sector establish close (business) relationships with foreign developers; such partnerships cannot be curbed by incompetent planning professionals; finally, the civil sector is forced to use its informal mechanisms in the struggle against regulatory capitalism. The following lines highlight the most remarkable episodes from both cases that serve for creating the 'lessons learnt' for similar sociospatial settings.

Serbia, as a country that has not only economic problems, but also a considerable lack of democratic political culture, proves to be more vulnerable than Greece to the effects of megaprojects. Eagle Hills was selected as the developer for BW without an open tender, i.e. in a bilateral negotiation process between the highest representatives of both the UAE and the Serbian governments, with extremely unfavourable conditions for Serbia. Developer Lamda for the Hellinikon project was chosen through a bidding procedure and, moreover, during the Syriza rule (2015-2109), the project was put on hold. The political narrative of the new ruling elite, however, inevitably resembles the discourse of the Serbian government counterparts.

Apart from a few individuals motivated by the NGOs' commitment, Serbian planners and architects, both academics and practitioners, did not provide a mature response to the decline of the national territorial capital. For example, the Serbian National Association of Architects' complaint against the original spatial concept of the BW project neglected the importance of complying to the basic procedural steps in such a megaproject development; instead, Serbian professionals criticized the BW proposal only for its architectural merits (Maruna 2015). In this way, the experts clearly show that they are still close to the paradigm of 'blueprint' planning, rather than being able to understand the complexity and causal reactions amongst the public, but also the civil and private sectors. Greek professionals, however, were active not only in raising their voices against the capital urbanisation, but also in providing alternative spatial solutions for protecting social goals.
The emergence of grassroot movements in both Serbia and Greece clearly indicate the extent of the usurpation of public goods and the violation of the public interest during privatisation. Compared to two active NGOs in Belgrade, in the Hellinikon case, a wider network of civil movements, also supported by professional associations and local and regional authorities, made the citizens' voice more influential. Finally, aimed at fighting against a ruling political regime in Serbia, the NGO 'Don't let Belgrade $\mathrm{d}(\mathrm{r})$ own' has been transformed into a political party.

Urban megaprojects lead to deregulation, and, consequently, question the role and purpose of urban planning, too. As a result, some contexts prove to be more vulnerable in protecting their own territorial capital. The attachment to institutional patronage in Greece and political favouritism in Serbia undermines the relevance of urban planning. However, transforming these conditions requires a variety of social, political and economic changes that go far beyond what plans can achieve. Some basic recommendations for reducing the negative externalities of megaproject development are as follows (Peric 2020a; Grubbauer and Camprag 2019; Zekovic et al. 2018):

(1) Clear recognition of national interest instead of glorifying the neoliberal principles;

(2) Dismiss of high-level politicians' nationalist narrative whilst advertising urban megaprojects;

(3) Decrease of political clientelism via urban megaprojects and introduction of anti-corruption mechanisms;

(4) Reassessment of regulatory mechanisms to precisely define the public interest;

(5) Real decentralization of power instead of its declarative announcement in the legislation;

(6) Strengthening the organizational and financial capacity of municipalities as a prerequisite to the bottom-up decision-making;

(7) Encouraging mutual trust, joint actions and transparent decision-making procedures amongst the representatives of public, private and civil sector;

(8) Boosting the autonomy of planners whilst creating the original planning concepts and tailor-made proposals;

(9) Use of innovative (both formal and informal) planning instruments to improve the public dialogue and facilitate participation of all relevant actors;

(10) Enabling an effective feedback between the public sector planners and citizens to create trust, mutual respect, and cooperation.

In sum, all these steps serve to reinforce strategic decision-making and eventually pave the way for a new planning culture. However, as planning culture grasps a variety of aspects-from the socio-political conditions of a society, to behaviours, habits and unwritten rules pursued by various 
representatives of social action, the transformation of a planning culture is considered a highly complex and incremental approach. Against such a comprehensive background, it becomes clear that planners are only one puzzle in the overall picture. It is not enough for planners to learn new skills and react flexibly to a rapidly changing world if such professional progress lacks support from the society in which it is embedded. It is why the Balkans, as a highly challenging setting almost always marked by political, economic and social turmoil, is particularly dependent on effective strategic cooperation-across scales and sectors-to properly cope with the complexity of megaproject development and protect its territorial capital from further erosion.

Funding Open Access funding provided by Swiss Federal Institute of Technology Zurich.

Open Access This article is licensed under a Creative Commons Attribution 4.0 International License, which permits use, sharing, adaptation, distribution and reproduction in any medium or format, as long as you give appropriate credit to the original author(s) and the source, provide a link to the Creative Commons licence, and indicate if changes were made. The images or other third party material in this article are included in the article's Creative Commons licence, unless indicated otherwise in a credit line to the material. If material is not included in the article's Creative Commons licence and your intended use is not permitted by statutory regulation or exceeds the permitted use, you will need to obtain permission directly from the copyright holder. To view a copy of this licence, visit http://creativecommons.org/licenses/by/4.0/.

\section{References}

Acebillo, P. 2015. Spatial and Transport Development Along European Corridors: Strengthening the Capacity of Local Stakeholders in Transnational Cooperation. Serbian Architectural Journal 7 (3): 343-366.

Aleksic, M. 2020. Srpske zemlje pre Nemanjica - od 7. do 10. veka (in Serbian). Belgrade: Laguna.

Bache, I., and M.V. Flinders, eds. 2004. Multi-level Governance. Oxford: Oxford University Press.

Böhme, K., S. Zillmer, M. Toptsidou, and F. Holstein. 2015. Territorial Governance and Cohesion Policy: Study. Brussels: European Parliament, Policy Department B: Structural and Cohesion Policies.

Brenner, N. 2004. New State Spaces: Urban Governance and Rescaling of Statehood. Oxford, New York: Oxford University Press.

CEC - Commission of the European Communities. 2008. Green Paper on Territorial Cohesion: Turning Territorial Diversity into Strength. Luxembourg: Office for Official Publications of the European Communities.

CSD - Committee on Spatial Development. 1999. ESDP - European Spatial Development Perspective. Towards Balanced and Sustainable Development of the Territory of the European Union. Luxembourg: Office for Official Publications of the European Communities.

Cook, A. 2010. The Expatriate Real Estate Complex: Creative Destruction and the Production of Luxury in Post-socialist Prague. International Journal of Urban and Regional Research 34 (3): $611-628$
Cope, B. 2015. Euro 2012 in Poland: Recalibrations of statehood in Eastern Europe. European Urban and Regional Studies 22 (2): 161-175.

Cukic, I., and A. Peric. 2019. Transformation of the Spatial Planning Approach in Serbia: Towards Strengthening the Civil Sector? In Spatial and Transport Infrastructure Development in Europe: Example of the Orient/East-Med Corridor, ed. B. Scholl, A. Peric, and M. Niedermaier, 272-290. Hannover: Academy for Spatial Research and Planning (ARL).

Cukic, I., D. Sekulic, Lj. Slavkovic, and A. Vilenica. 2015. Report from Belgrade Waterfront. Eurozine, 6 May, http://www.euroz ine.com/report-from-belgrade-waterfront/. Accessed 1 June 2020.

Cvetinovic, M., Z. Nedovic-Budic, and J.-C. Bolay. 2017. Decoding Urban Development Dynamics Through Actor-Network Methodological Approach. Geoforum 82: 141-157.

Davoudi, S., and I. Strange. 2009. Conceptions of Space and Place in Strategic Spatial Planning. London: Routledge.

del Cerro Santamaria, G., ed. 2013. Urban Megaprojects: A Worldwide View. Bingley: Emerald books.

D'hondt, F. 2017. Balkan Planning at Crossroads: The New Urban Agenda as the Opportunity for 'Business as Unusual'. Talk presented at the Balkan Architectural Biennale; 21 December, Belgrade, Serbia.

Diklic, A. 2014. Belgrade, the Eternal City: A Sentimental Journey Through History. Belgrade: Skordisk.

Eagle Hills 2015. Belgrade Waterfront Project (brochure). Belgrade: Eagle Hills.

EC - European Commission. 2016. Urban Agenda for EU. Brussels: Office for Official Publications of the European Communities.

ESPON - European Spatial Planning Observation Network. 2013. Towards Better Territorial Governance in Europe. A Guide for Practitioners, Policy and Decision Makers. Torino: ESPON \& Politecnico di Torino.

EU Ministers. 2011. Territorial Agenda of the European Union: Towards an Inclusive, Smart and Sustainable Europe of Diverse Regions. Agreed on the Occasion of the Informal Ministerial Meeting of Ministers Responsible for Spatial Planning and Territorial Development; 19 May, Hungary.

Evmolpidis, J. 2016. Urban Development in Athens: Current Overview. Talk Presented at the ARL Workshop; 24 November, Athens, Greece.

Faludi, A. 2012. Multi-level (Territorial) Governance: Three Criticisms. Planning Theory \& Practice 13 (2): 197-211.

Faludi, A. 2018. The Poverty of Territorialism: A Neo-Medieval View of Europe and European Planning. Cheltenham: Edward Elgar Publishing Limited.

Flyvbjerg, B. 2009. Survival of the Unfittest: Why the Worst Infrastructure Gets Build and What Can Do About It. Oxford Review Economic Policy 25 (3): 344-367.

Flyvbjerg, B. 2014. What You Should Know About Megaprojects and Why: An Overview. Project Management Journal 45 (2): 6-19.

Flyvbjerg, B. 2017. Introduction: The Iron Law of Megaproject Management. In The Oxford Handbook of Megaproject Management, ed. B. Flyvbjerg, 1-18. Oxford: Oxford University Press.

Getimis, P., and G. Giannakourou. 2014. The Evolution of Spatial Planning in Greece after the 1990s: Drivers, Directions and Agents of Change. In Spatial Planning Systems and Practices in Europe, ed. M. Reimer, P. Getimis, and H.H. Blotevogel, 149-168. New York: Routledge.

Giannakourou, G. 2011. Europeanization, Actor Constellations and Spatial Policy in Greece. disP - The Planning Review 47: 32-41.

Grubbauer, M., and N. Camprag. 2019. Urban Megaprojects, NationState Politics and Regulatory Capitalism in Central and Eastern Europe: The Belgrade Waterfront project. Urban Studies 56 (4): 649-671. 
Hadjimichalis, C. 2011. Uneven Geographical Development and SocioSpatial Justice and Solidarity: European Regions after the 2009 Financial Crisis. European Urban and Regional Studies 18 (3): 254-274.

Hajdu, Z., and S. Racz. 2011. Urbanisation, State Formation Processes and New Capital Cities in the Western Balkans. Acta Universitatis Palackianae Olomucensis - Geographica 42 (2): 63-77.

Hooghe, L., and G. Marks. 2010. Types of Multi-level Governance. In Types of Multilevel Governance, ed. H. Enderlein, S. Wälti, and M. Zürn, 17-31. Cheltenham: Edward Elgar Publishing Limited.

Kampouris, N. 2019. The Hellinikon Project: Greece's Modern Tale of Agony and Ambition. Greek Reporter, 15 September, https://greec e.greekreporter.com/2019/09/15/the-hellinikon-project-greecesmodern-tale-of-agony-and-ambition/. Accessed 26 May 2020.

Karadimitriou, N., and T. Pagonis. 2019. Planning Reform and Development Rights in Greece: Institutional Persistence and Elite Rule in the Face of the Crisis. European Planning Studies 27 (6): $1217-1234$.

Komninos, A. 2014. Hellinikon: Tactics of Capital Urbanization and the Collective Superstructure. In Globalizing Architecture: Flows and Disruptions. Proceedings of the 102nd ACSA Annual Meeting; 10-12 April, eds. J. Stuart and M. Wilson, pp. 139-149. Miami Beach: Association of Collegiate Schools of Architecture.

Kovacevic, B. 2014. Vucic's Belgrade: Walled City (interview by B. Mihajlovic) (in Serbian). Radio Slobodna Evropa, 13 July, http:// aas.org.rs/bojan-kovacevic-vucicev-beograd-zazidani-grad/. Accessed 26 Jan 2019.

Lazarevic-Bajec, N. 2009. Rational or Collaborative Model of Urban Planning in Serbia: Institutional Limitations. Serbian Architectural Journal 1: 81-106.

Lee, C.C.M. 2012. The Fourth Typology: Dominant Type and the Idea of the City. PhD thesis, TU Delft, Delft, the Netherlands.

Le Gales, P. 1998. Regulation, Territory and Governance. International Journal of Urban and Regional Research 22 (3): 482-506.

Maruna, M. 2015. Can Planning Solutions Be Evaluated Without Insight into the Process of Their Creation? In Plan Together-Right Now-Overall. Proceedings of the REAL CORP 2015 Conference, 5-7 May, Ghent, Belgium, eds. M. Schrenk, V. Popovich, P. Zeile, P. Elisei, and C. Beyer, 121-132. Vienna: REAL CORP.

Maricic, T., M. Cvetinovic, and J.-C. Bolay. 2018. Participatory Planning in the Urban Development of Post-Socialist Serbia. In A Support to Urban Development Process, ed. J.-C. Bolay, T. Maricic, and S. Zekovic, 1-28. CODEV EPFL/IAUS: Lausanne.

Milionis, S. 2010. City Marketing in Greece: The Post-Olympic Use of Hellinikon Former Airport Site. Regional Science Inquiry Journal 2: $151-172$.

Mrdjenovic, T. 2013. Urban Regeneration: Questioning the Subject. Technics Technologies Education Management 8 (3): 1350-1354.

Mrdjenovic, T. 2014. Teaching Method: 'Integrative Urban Design Game' for Soft Urban Regeneration. Spatium 31: 57-65.

Municipality of Hellinikon-Argyroupoli. 2013. The Site of Hellinikon in Athens: Development for Whom? https://www.elliniko-argyr oupoli.gr/article.php?id=2569. Accessed 1 June 2020.

National Herald. 2019. Lambda Will Buy Out Hellinikon Airport Development Partners. 20 Sept, https://www.thenationalhera ld.com/archive_whats_new/arthro/lambda_will_buy_out_helle nikon_airport_development_partners-23442/. Accessed 29 May 2020.

Nedovic-Budic, Z., and B. Cavric. 2006. Waves of Planning: Framework for Studying the Evolution of Planning Systems and Empirical Insights from Serbia and Montenegro. Planning Perspectives 21 (4): 393-425.

Nedovic-Budic, Z., S. Zekovic, and M. Vujosevic. 2012. Land Privatization and Management in Serbia-Policy in Limbo. Journal of Architectural and Planning Research 29: 307-317.
OG RG 4062/2012 (Official Gazette of the Republic of Greece 4062/2012). Development of the Athens Former International Airport Hellinikon.

OG RS 1/2012 (Official Gazette of the Republic of Serbia 1/2012). Ordinance on the Methodology and Procedures on Realization the Projects of Importance for the Republic of Serbia.

OG RS 132/2014 (Official Gazette of the Republic of Serbia 132/2014). The Act on Planning and Construction.

OG RS 3/2013 (Official Gazette of the Republic of Serbia 3/2013). The Act Confirming the Agreement on Cooperation Between the Government of the Republic of Serbia and the Government of United Arab Emirates.

OG CB 70/2014 (Official Gazette of the City of Belgrade 70/2104). The Amendments on the Master Plan of Belgrade.

OG RS 7/2015 (Official Gazette of the Republic of Serbia 7/2015). The spatial plan of Belgrade Waterfront.

OG RS 34/2015 (Official Gazette of the Republic of Serbia 34/2015). Lex Specialis - The Law on Establishing the Public Interest and Special Procedures of Expropriation and the Issuance of Building Permit for the Project "Belgrade Waterfront".

Papaioannou, A., and C. Nikolakopoulou. 2016. Greek Cities in Crisis: Context, Evidence, Response. In Cities in Crisis: Sociospatial impacts of the Economic Crisis in Southern European Cities, ed. J. Knieling and F. Othengrafen, 172-189. New York: Routledge.

Papamichail, T., and A. Peric. 2018. Informal democracy in Patras, Greece: A Mechanism for Improved Planning? Cities 74: 334-342.

Peric, A. 2016. Integrated Spatial and Transport Development: A Multilevel Perspective. In CODE: ATHENS Railway and City Development in Athens, ed. B. Scholl, K. Moraitis, V. Pappas, A. Peric, and I. Frezadou, 37-47. Zurich: Institute for Spatial and Landscape Development, ETH Zurich.

Peric, A. 2019. Multi-level Governance as a Tool for Territorial Integration in Europe: Example of the Orient/East-Med Corridor. In Spatial and Transport Infrastructure Development in Europe: Example of the Orient/East-Med Corridor, ed. B. Scholl, A. Peric, and M. Niedermaier, 91-105. Hannover: Academy for Spatial Research and Planning (ARL).

Peric, A. 2020a. Public Engagement Under Authoritarian Entrepreneurialism: The Belgrade Waterfront Project. Urban Research and Practice 13 (2): 213-227.

Peric, A. 2020b. Citizen Participation in Transitional Society: The Evolution of Participatory Planning in Serbia. In Learning from Arnstein's Ladder: From Citizen Participation to Public Engagement, ed. M. Lauria and C. Schively Slotterback, 91-109. New York: Routledge Press.

Peric, A. and C. Hoch. 2017. Spatial Planning Across European Planning Systems and Social Models: A Look Through the Lens of Planning Cultures of Switzerland, Greece and Serbia. In Spaces of Dialog for Places of Dignity: Fostering the European Dimension of Planning. E-Proceedings of the AESOP 2017 Conference; 11-14 July, Lisbon, Portugal, eds. J. A. Ferreira et al., 1247-1258. Lisbon: University of Lisbon.

Peric, A., and M. Miljus. 2017. Spatial and Urban Planning in Serbia: A Look Through the Lens of Deliberative Approach. Spatium 37: 49-57.

Peric, A., and M. Niedermaier. 2019. Orient/East-Med Corridor: Challenges and Potentials. In Spatial and Transport Infrastructure Development in Europe: Example of the Orient/East-Med Corridor, ed. B. Scholl, A. Peric, and M. Niedermaier, 35-70. Hannover: Academy for Spatial Research and Planning (ARL).

Peric, A., and B. Scholl. 2017. Transnational Cooperation in Europe: The Example of Integrated Spatial and Transport Development Along the Hamburg-Athens Corridor. Athens Journal of Sciences 4 (2): 101-114. 
Piattoni, S. 2016. Exploring European Union Macro-regional Strategies Through the Lens of Multilevel Governance. In A 'Macroregional' Europe in the Making: Theoretical Approaches and Empirical Evidence, ed. S. Gänzle and K. Kern, 75-98. Basingstoke: Palgrave Macmillan.

Pollalis, S.N. 2012. Hellinikon Urban Development Model: Former Athens Airport \& Agios Kosmas Coast, 17 May 2012, Madrid, Spain.

Prentou, P. 2012. More Athenian Sociospatial Injustice in the Works? Creating a Metropolitan Park at the Former Hellinikon International Airport of Athens. In Planning to Achieve: The Need for New Discourses and Practices in Spatial Development and Planning. Proceedings of the AESOP 2012 Conference, 11-15 July, Ankara, Turkey, eds. M. Balamir, M. Ersoy, and E. Babalik Sutcliffe (eds.), 1-21. Ankara: METU.

Radojevic, R. 2017. The Belgrade Waterfront Project Through the Lens of Technical Requirements. Talk Presented at the ARL Workshop; 27 April, Belgrade, Serbia.

Rhodes, R. 1996. The New Governance: Governing Without Government. Political Studies 44: 652-667.

Scholl, B. (ed.) 2012. SAPONI: Spaces and Projects of National Importance. Zurich: vdf Hochschulverlag, ETH Zurich.

Scholl, B., A. Peric, and M. Niedermaier, eds. 2019. Spatial and Transport Infrastructure Development in Europe: Example of the Orient/East-Med corridor. Hannover: Academy for Spatial Research and Planning (ARL).

Swyngedouw, E., F. Moulaert, and A. Rodriguez. 2002. Neoliberal Urbanization in Europe: Large-scale Urban Development Projects and the New Urban Policy. Antipode 34 (3): 542-577.

The Hellinikon Project. 2020. A Model City. https://thehellinikon. com/a-model-city/. Accessed 13 Jan 2020.

UN (United Nations). 2015. Transforming Our World: The 2030 Agenda for Sustainable Development. A/RES/70/1.
UN (United Nations). 2017. New Urban Agenda. Ecuador: Habitat III Secretariat.

Vourdas, A. 2016. The Projects to Construct the Greek Part of the Orient/East-Med Corridor. Talk Presented at the ARL Workshop; 24 November, Athens, Greece.

Vujosevic, M. 2010. Collapse of Strategic Thinking, Research and Governance in Serbia and Possible Role of the Spatial Plan of the Republic of Serbia. Spatium 23: 22-29.

Vujosevic, M., and Z. Nedovic-Budic. 2006. Planning and Societal Context-The Case of Belgrade, Serbia. In The Urban Mosaic of post-socialist Europe: Space, Institutions and Policy, ed. S. Tsenkova and Z. Nedovic-Budic, 275-294. Heilderberg: Springer.

Zekovic, S., M. Vujosevic, and T. Maricic. 2015. Spatial Regularization, Planning Instruments and Urban Land Market in a Postsocialist Society: The Case of Belgrade. Habitat International 48: $65-78$

Zekovic, S., T. Maricic, and M. Vujosevic. 2018. Megaprojects as an Instrument of Urban Planning and Development: Example of Belgrade Waterfront. In Technologies for Development: From Innovation to Social Impact, ed. S. Hostetter, S. Najih Besson, and J.-C. Bolay, 153-164. London: Springer.

Zifou, M. 2015. Greek Spatial Planning and the Crisis. In City of Crisis: The Multiple Contestation of Southern European Cities, ed. F. Eckardt and J.R. Sanchez, 155-178. Bielefeld: Transcript Verlag.

Zizek, S. 1999. The Spectre of Balkan. The Journal of the International Institute 6(2). https://quod.lib.umich.edu/j/jii/47509 78.0006.202? view=text;rgn=main. Accessed 26 May 2020.

Publisher's Note Springer Nature remains neutral with regard to jurisdictional claims in published maps and institutional affiliations. 